\title{
SWOT analysis of Pakistan's textile and clothing industry
}

\section{REZUMAT - ABSTRACT}

\section{Analiza SWOT a industriei textile și de îmbrăcăminte din Pakistan}

Industria textilă și de îmbrăcăminte din Pakistan este unul dintre jucătorii importanți ai comerțului global de textile și îmbrăcăminte, fiind, de asemenea, o piatră de temelie pentru economia națională. Deși industria textilă și de îmbrăcăminte din Pakistan posedă resurse abundente de materii prime (bumbac) și de forță de muncă ieftină și abundentă, aceasta s-a confruntat cu multe probleme în ultimii ani. În acest moment, analiza SWOT este una dintre metodele care pot fi utilizate pentru analiza situației curente. Acest studio urmărește să prezinte situația actuală a industriei textile și de îmbrăcăminte din Pakistan prin analiza SWOT. Astfel, poate fi completat un decalaj în care studiile academice sunt inadecvate. În plus, studiul contribuie la dezvoltarea strategiei companiilor pakistaneze de textile și îmbrăcăminte și a oficialilor guvernamentali. În conformitate cu scopul cercetării, au fost determinate în primul rând punctele forte și dezavantajele industriei textile și de îmbrăcăminte din Pakistan. Ulterior, au fost analizate oportunitățile și amenințările comerțului național și internațional cu produse textile și de îmbrăcăminte. În cele din urmă, datele obținute au fost analizate și evaluate și au fost elaborate sugestii pentru viitorul industriei.

Cuvinte-cheie: industria textilă și de îmbrăcăminte din Pakistan, analiza SWOT, competitivitate, comerțul cu produse textile și îmbrăcăminte

\section{SWOT analysis of Pakistan's textile and clothing industry}

Pakistan's textile and clothing industry is one of the significant players of global textile and clothing trade as well as being a corner stone for its national economy. Although Pakistan's textile and clothing industry possesses abundant raw material resources (cotton) and cheap and abundant labour, it has confronted with many issues in recent years. At this point, SWOT analysis is one of the methods which can be used for the analysis of current situation. This research aims to reveal the present situation of Pakistan's textile and clothing industry with SWOT analysis. Thus, a gap can be filled in which academic studies are inadequate. Besides, the study contributes to the strategy development of Pakistan's textile and clothing companies and government executives. In accordance with the aim of the research, the strengths and weakness of Pakistan's textile and clothing industry are determined primarily. Afterwards, opportunities and threats, which can be faced within national and international textile and clothing trade are analyzed. Finally, the obtained data are analyzed and evaluated and suggestions are made for the future of the industry.

Keywords: Pakistan's textile and clothing industry, SWOT analysis, competitiveness, textile and clothing trade

\section{INTRODUCTION}

Asian countries have recently become the rising stars of global textile and clothing trade. Pakistan, which is one of these countries, is a leading global textile exporter. Pakistan textile and clothing industry, which is a locomotive of Pakistan economy, attracts attention with increasing export ratios. However, the academic studies within the literature, which analyze and scrutinize Pakistan's textile and clothing industry, which is one of the significant actors of global textile and clothing trade, in all aspects, are inadequate and lack of current information. Therefore, a current situation evaluation study, which can analyze the current situation of Pakistan textile and clothing industry and which can be helpful for developing future strategies, is needed. In this context, primarily, current situation of Pakistan's textile and clothing industry is analyzed in detail.

As known, textile is the basic industry of Pakistan. It is accorded as the backbone of Pakistan's economy as it is the remarkable source of Pakistan's export earnings. Textile industry is the single largest determinant for the economic growth of the country due to its share in the economy as well as its contribution to exports, employment, foreign exchange earnings, investment and revenue generation [1]. Textile and clothing industry approximately constitutes $62 \%$ of Pakistan's exports by 2016 (table 1).

Pakistan's textile industry provides approximately $\% 40$ of industrial labour force, $40 \%$ of manufacturing sector's banking credits, $8 \%$ of gross domestic product. According to the International Cotton Advisory Committee, Pakistan is the fourth largest cotton producer and third largest cotton consumer in the world. In addition, Pakistan is the world's second largest cotton yarn exporter and third largest cotton cloth manufacturer and exporter [3].

Easily available cheap labour and basic raw material (cotton) has played a primary role in the growth of Pakistan's textile industry. Pakistan's textile industry, which is the leading sector of industrial manufacturing, is based on abundant supply of indigenous cotton. In other words, it depends on cotton agriculture. 
SHARE OF TEXTILE AND CLOTHING INDUSTRY IN PAKISTAN'S GLOBAL TRADE (MILLION US DOLLAR) [2]

\begin{tabular}{|l|c|c|c|c|c|c|}
\hline & $\mathbf{2 0 1 1}$ & $\mathbf{2 0 1 2}$ & $\mathbf{2 0 1 3}$ & $\mathbf{2 0 1 4}$ & $\mathbf{2 0 1 5}$ & $\mathbf{2 0 1 6}$ \\
\hline Pakistan's total exports & 25,383 & 24,567 & 25,121 & 24,706 & 22,188 & 20,435 \\
\hline Pakistan's textile and clothing exports & 13,632 & 12,919 & 13,890 & 14,068 & 13,255 & 12,783 \\
\hline Share of textile and clothing in exports (\%) & 53.71 & 52.59 & 55.29 & 56.94 & 59.74 & 62.55 \\
\hline Pakistan's total imports & 44,012 & 44,105 & 44,647 & 47,434 & 44,219 & 47,155 \\
\hline Pakistan's textile and clothing imports & 1,332 & 1,148 & 1,313 & 1,631 & 1,724 & 1,821 \\
\hline Share of textile and clothing in imports (\%) & 3.03 & 2.60 & 2.94 & 3.44 & 3.90 & 3.86 \\
\hline
\end{tabular}

Therefore, whatever affects the cotton crop is likely to affect the performance of the textile industry [4].

Today, Pakistan has an integrated textile industry which comprises cotton spinning, cotton weaving, cotton fabric, fabric processing, home textiles, towels, hosiery, knitwear and clothing. These are manufactured both on large scale units and small and medium cottage units [5]. The major concentration of the industry is in the Karachi, Hyderabad, Multan, Lahore, Gujranwala and Faisalabad [1].

Since 2000, Government of Pakistan has been emphasizing the value added production in textile industry. For this purpose, comprehensive Textile Vision-2000 policy was formulated in order to bring innovations, implement market driven strategies and encounter the challenges of World Trade Organization. However, the progress of value added production in weaving and spinning has not been satisfactory [6]. In the mid of 2000s, Pakistan's textile production has seen a sharp increase in investment, which coupled with Pakistan's pool of inexpensive labour. It has attracted global brands, particularly in the manufacture of sportswear. Nevertheless, the industry's performance has been undermined recently by increased international competition, particularly after the phaseout of the Multifibre Agreement in December 2004. In addition, numerous infrastructure bottlenecks, particularly in the energy sector, crippled textiles production and squeezed the profit margins of textile and clothing producers [7].
In spite of these disadvantages, Pakistan's share in global textile exports is \%2,7 by 2016 and it is theseventh biggest textile exporter of the world [8]. Textile and clothing export and import figures of Pakistan and its shares within world textile trade are shown in table 2.

Textile and clothing exports of Pakistan according to product segments are shown in table 3 whereas the imports figures according to product segments are shown in table 4. As it can be seen, Pakistan mostly exports cotton (fibre, yarn and fabric), other made-up textile articles, knitted apparel and clothing accessories and woven apparel and clothing accessories. The biggest shares within cotton belong to cotton yarn other than sewing thread (containing $>=85 \%$ cotton by weight) and woven fabrics of cotton (containing $>=85 \%$ cotton by weight and weighing $>200$ $\mathrm{g} / \mathrm{m}^{2}$ ), whereas lion's share within other made-up textile articles belongs to bed linen, table linen, toilet linen and kitchen linen of all types of textile materials. If the imported textile and clothing items of Pakistan are analyzed, it can be seen that Pakistan mostly imports cotton (fibre, yarn and fabric), man-made filaments (fibre, yarn and fabric) and man-made staple fibres (fibre, yarn and fabric). The lion's share within cotton belongs to neither carded nor combed cotton, whereas the biggest shares within man-made filaments and staples belong to synthetic filament yarn (including synthetic monofilaments of $<67$ decitex) and artificial staple fibres (not carded or combed).

\begin{tabular}{|l|c|c|c|c|c|c|}
\multicolumn{1}{|c|}{ Table 2} \\
\hline World textile export & $\mathbf{2 0 1 1}$ & $\mathbf{2 0 1 2}$ & $\mathbf{2 0 1 3}$ & $\mathbf{2 0 1 4}$ & $\mathbf{2 0 1 5}$ & $\mathbf{2 0 1 6}$ \\
\hline Pakistan's textile export & 293,844 & 283,430 & 303,503 & 313,621 & 290,519 & 284,064 \\
\hline Pakistan's share in world textile export & 9,082 & 8,705 & 9,341 & 9,077 & 8,232 & 7,680 \\
\hline World textile import & 3.09 & 3.07 & 3.08 & 2.89 & 2.83 & 2.70 \\
\hline Pakistan's textile import & 311,299 & 301,950 & 324,505 & 335,258 & 308,108 & 303,934 \\
\hline Pakistan's share in world textile import & 1,245 & 1,077 & 1,245 & 1,545 & 1,621 & 1,716 \\
\hline World clothing export & 0.40 & 0.36 & 0.38 & 0.46 & 0.52 & 0.56 \\
\hline Pakistan's clothing export & 418,523 & 421,554 & 462,005 & 490,168 & 453,894 & 444,444 \\
\hline Pakistan's share in world clothing export & 4,550 & 4,214 & 4,549 & 4,991 & 5,023 & 5,103 \\
\hline World clothing import & 1.09 & 1.00 & 0.98 & 1.02 & 1.11 & 1.14 \\
\hline Pakistan's clothing import & 438,190 & 457,034 & 502,610 & 525,977 & 498,525 & 468,793 \\
\hline Pakistan's share in world clothing import & 87 & 71 & 68 & 86 & 103 & 105 \\
\hline
\end{tabular}




\begin{tabular}{|l|c|c|c|c|c|}
\hline & $\mathbf{2 0 1 2}$ & $\mathbf{2 0 1 3}$ & $\mathbf{2 0 1 4}$ & $\mathbf{2 0 1 5}$ & $\mathbf{2 0 1 6}$ \\
\hline 50-Silk (fibre, yarn, fabric) & 686 & 1,825 & 1,375 & 1,823 & 1,577 \\
\hline 51-Wool and animal hair (fibre, yarn, fabric) & 12,203 & 16,093 & 14,166 & 9,332 & 6,795 \\
\hline 52-Cotton (fibre, yarn, fabric) & $5,225,694$ & $5,333,784$ & $4,731,369$ & $4,040,271$ & $3,497,374$ \\
\hline 53-Other vegetable textile fibres (fibre, yarn, fabric) & 5,629 & 2,140 & 1,282 & 3,046 & 3,119 \\
\hline 54-Man-made filaments (fibre, yarn, fabric) & 34,127 & 30,349 & 33,423 & 25,656 & 30,336 \\
\hline 55-Man-made staple fibres (fibre, yarn, fabric) & 449,180 & 418,173 & 417,658 & 302,343 & 220,487 \\
\hline 56-Wadding, felt, nonwovens and special yarns & 16,569 & 27,340 & 87,828 & 113,957 & 89,055 \\
\hline 57-Carpets and other textile floor coverings & 121,380 & 128,302 & 123,268 & 105,242 & 88,773 \\
\hline 58-Special woven fabrics, lace and embroidery & 25,959 & 21,917 & 22,067 & 18,916 & 22,784 \\
\hline 59-Laminated textile fabrics & 13,284 & 12,663 & 10,376 & 8,942 & 6,369 \\
\hline 60-Knitted fabrics & 36,085 & 32,565 & 35,969 & 41,862 & 36,064 \\
\hline 61-Knitted apparel and clothing accessories & $2,006,290$ & $2,105,321$ & $2,402,619$ & $2,359,608$ & $2,347,471$ \\
\hline 62-Woven apparel and clothing accessories & $1,694,386$ & $1,854,926$ & $1,984,656$ & $2,127,462$ & $2,253,021$ \\
\hline 63-Other made-up textile articles & $3,285,353$ & $3,685,485$ & $3,906,465$ & $3,759,721$ & $3,803,987$ \\
\hline
\end{tabular}

Table 4

\begin{tabular}{|l|c|c|c|c|c|}
\hline & $\mathbf{2 0 1 2}$ & $\mathbf{2 0 1 3}$ & $\mathbf{2 0 1 4}$ & $\mathbf{2 0 1 5}$ & $\mathbf{2 0 1 6}$ \\
\hline 50-Silk (fibre, yarn, fabric) & 33,949 & $\mathbf{2 4 , 6 4 0}$ & $\mathbf{3 8 , 8 6 6}$ & $\mathbf{5 0 , 4 1 6}$ & $\mathbf{5 2 , 2 6 5}$ \\
\hline 51-Wool and animal hair (fibre, yarn, fabric) & 13,885 & 11,681 & 19,803 & 18,072 & 20,025 \\
\hline 52-Cotton (fibre, yarn, fabric) & 683,983 & $1,046,709$ & 741,596 & 662,978 & 719,254 \\
\hline 53-Other vegetable textile fibres (fibre, yarn, fabric) & 53,230 & 50,524 & 48,426 & 48,058 & 42,159 \\
\hline 54-Man-made filaments (fibre, yarn, fabric) & 529,861 & 527,170 & 676,963 & 720,153 & 721,791 \\
\hline 55-Man-made staple fibres (fibre, yarn, fabric) & 539,396 & 532,440 & 766,145 & 782,754 & 687,043 \\
\hline 56-Wadding, felt, nonwovens and special yarns & 50,122 & 55,711 & 86,725 & 112,254 & 119,426 \\
\hline 57-Carpets and other textile floor coverings & 24,434 & 15,596 & 17,566 & 20,958 & 21,742 \\
\hline 58-Special woven fabrics, lace and embroidery & 45,625 & 44,932 & 46,017 & 30,979 & 36,791 \\
\hline 59-Laminated textile fabrics & 69,654 & 62,775 & 82,661 & 88,216 & 107,067 \\
\hline 60-Knitted fabrics & 33,365 & 41,016 & 74,884 & 122,101 & 171,495 \\
\hline 61-Knitted apparel and clothing accessories & 23,641 & 25,019 & 33,440 & 44,129 & 53,363 \\
\hline 62-Woven apparel and clothing accessories & 26,815 & 22,254 & 33,311 & 41,384 & 30,116 \\
\hline 63-Other made-up textile articles & 197,537 & 198,162 & 230,203 & 280,988 & 314,334 \\
\hline
\end{tabular}

New strategies should be developed in order to increase Pakistan's textile and clothing exports. But before strategic development, it is necessary to identify the internal capabilities and weaknesses of Pakistan's textile and clothing industry. SWOT analysis is the one of the self-evaluating tools for measuring internal capabilities and weaknesses.

SWOT analysis method falls back upon four research directions as; strengths, weaknesses, opportunities and threats. The phases of SWOT analysis encompass three stages: the identification of strengths, weaknesses, opportunities and threats; the analysis of strengths, weaknesses, opportunities and threats and the formulation of the strategic alternatives [11]. It is a good tool for understanding the current situation of a company/industry/country and also helps to improve the status of company/industry/country. It also devises a plan for the future; one that employs the existing strengths, present and future opportunities and defends against the threats. The SWOT analysis of Pakistan's textile and clothing industry will help to identify the weaknesses of the present industry and also will help to rectify those weaknesses by using strengths and opportunities. The SWOT analysis will help to find solutions for threats, so that the industry will grow and become competitive against the rivals like China and India and also against the new growing countries like Bangladesh and Vietnam.

\section{THE PURPOSE AND THE METHOD OF THE RESEARCH}

Pakistan's textile and clothing industry has made significant progresses in recent years. These progresses are reflected well on country's economic development and industry's international trade. Thus, it is the seventh biggest textile exporter of the world. Abundant raw material resources, cheap and abundant labour force and preferential trade agreements with USA and European Union have significantly contributed to this rapid progress. Besides, textile and 


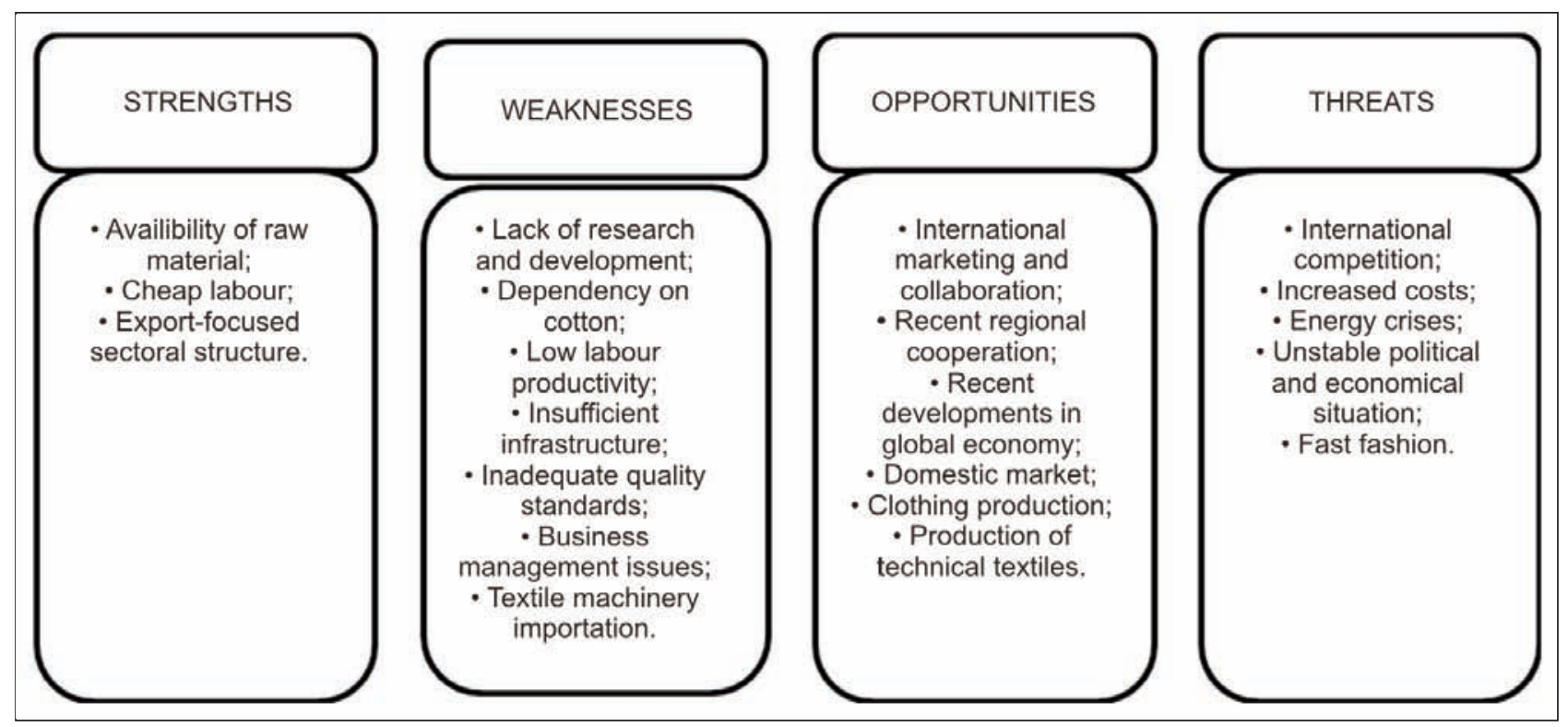

Fig. 1. SWOT analysis of Pakistan's textile and clothing industry

clothing cluster within South Asia has also contributed to this development.

This research aims to reveal the present situation of Pakistan's textile and clothing industry with SWOT analysis. Thus, a gap can be filled in which academic studies are inadequate. Besides, the study contributes to the strategy development of Pakistan's textile companies and government executives, supplier companies and countries and rival companies and countries.

In accordance with the aim of the research, the strengths and weakness of Pakistan's textile and clothing industry are determined primarily. Afterwards, opportunities and threats, which can be faced within national and international textile trade, are analyzed. Finally, the obtained data are analyzed and evaluated and suggestions are made for the future of the industry.

\section{SWOT ANALYSIS OF PAKISTAN'S TEXTILE AND CLOTHING INDUSTRY}

SWOT analysis of Pakistan's textile and clothing industry is summarized in figure 1.

\section{Strengths of Pakistan's Textile and Clothing Industry}

\section{Availability of raw material}

Pakistan has high self-sufficiency in raw material. According to Cotton Incorporated [12], Pakistan

\begin{tabular}{|l|c|c|c|c|}
\hline \multicolumn{1}{|c|}{ Country } & $\mathbf{2 0 1 3 / 1 4}$ & $\mathbf{2 0 1 4 / 1 5}$ & $\mathbf{2 0 1 5 / 1 6}$ & $\mathbf{2 0 1 6 / 1 7}$ \\
\hline India & 31.0 & 29.5 & 26.4 & 27.0 \\
\hline China & 32.8 & 30.0 & 22.0 & 22.8 \\
\hline USA & 12.9 & 16.3 & 12.9 & 17.2 \\
\hline Pakistan & 9.5 & 10.6 & 7.0 & 7.7 \\
\hline Brazil & 8.0 & 7.0 & 5.9 & 6.8 \\
\hline Australia & 4.1 & 2.3 & 2.9 & 4.2 \\
\hline Uzbekistan & 4.1 & 3.9 & 3.8 & 3.7 \\
\hline Turkey & 2.3 & 3.2 & 2.7 & 3.2 \\
\hline Burkina Faso & 1.3 & 1.4 & 1.1 & 1.3 \\
\hline Turkmenistan & 1.6 & 1.5 & 1.5 & 1.3 \\
\hline Mali & 0.9 & 1.0 & 1.0 & 1.2 \\
\hline Mexico & 0.9 & 1.3 & 0.9 & 0.8 \\
\hline Greece & 1.4 & 1.3 & 1.0 & 1.0 \\
\hline
\end{tabular}

takes the 13 place within the leading cotton exporters of the world. However, it takes the fourth place within the biggest cotton producers of the world (table 5). Cotton is the main crop of Pakistan and textile industry mainly depends on cotton. In order to benefit from abundant cotton resources, Pakistan's textile industry has moved towards industrialization. Cotton (fibre, yarn and fabric) export and import figures of Pakistan throughout the years are shown in table 6 .

\begin{tabular}{|l|c|c|c|c|c|}
\hline & $\mathbf{2 0 1 2}$ & $\mathbf{2 0 1 3}$ & $\mathbf{2 0 1 4}$ & $\mathbf{2 0 1 5}$ & $\mathbf{2 0 1 6}$ \\
\hline 52-Cotton (fibre, yarn, fabric) export & $5,225,694$ & $5,333,784$ & $4,731,369$ & $4,040,271$ & $3,497,374$ \\
\hline Annual \% change & - & 2,07 & $-11,29$ & $-14,61$ & $-13,44$ \\
\hline 52-Cotton (fibre, yarn, fabric) import & 683,983 & $1,046,709$ & 741,596 & 662,978 & 719,254 \\
\hline Annual \% change & - & 53.03 & -29.15 & -10.60 & 8.49 \\
\hline Foreign trade balance of cotton & $4,541,711$ & $4,287,075$ & $3,989,773$ & $3,377,293$ & $2,778,120$ \\
\hline
\end{tabular}




\begin{tabular}{|l|c|c|}
\hline \multicolumn{1}{|c|}{ Occupation } & $\begin{array}{c}\text { Wages per month } \\
\text { (for 26 working days) (US\$) }\end{array}$ & $\begin{array}{c}\text { Wages per day } \\
\text { (for 8 hours shift) (US\$) }\end{array}$ \\
\hline $\begin{array}{l}\text { Technical manager } \\
\text { Production manager } \\
\text { Spinning/weaving/dyeingmaster }\end{array}$ & $\begin{array}{l}\text { Wages alter due to the mutual } \\
\text { bargaining between employers } \\
\text { and employees }\end{array}$ & $\begin{array}{c}\text { Wages alter due to the mutual } \\
\text { bargaining between employers } \\
\text { and employees }\end{array}$ \\
\hline $\begin{array}{l}\text { Head jobber } \\
\text { Production supervisor } \\
\text { Shift in charge } \\
\text { Assistant spinning/weaving master }\end{array}$ & 88.54 & 3.41 \\
\hline $\begin{array}{l}\text { Highly skilled in printing, dyeing and } \\
\text { finishing }\end{array}$ & & 3.07 \\
\hline $\begin{array}{l}\text { Semi skilledin printing, dyeing and } \\
\text { finishing }\end{array}$ & 79.92 & 2.65 \\
\hline $\begin{array}{l}\text { Unskilled in printing, dyeing and } \\
\text { finishing }\end{array}$ & 68.82 & 2.55 \\
\hline
\end{tabular}

\section{Cheap labour}

Pakistan's textile industry provides approximately $\% 40$ of industrial labour force [3]. Cheap labour is the major strength of Pakistan's economy. Cheap labour supply strengthens the textile industry's position and at the same time it helps to increase the number oforders from USA and European markets. The wages of Pakistan's textile industry workers are given in table 7 .

\section{Export-focused sectoral structure}

As it is mentioned before, Pakistan's textile and clothing industry approximately constitutes $62 \%$ of Pakistan's exports by 2016. Also Pakistan's share in global textile exports is $\% 2,7$ by 2016 and it is the seventh biggest textile exporter of the world. As it can be seen, the sector is focused on exportation and this situation strengthens sector's structure.

\section{Weaknesses of Pakistan's Textile and Clothing Industry}

\section{Lack of research and development}

There is lack of efficient research and development and training in Pakistan's textile and clothing sector [14]. The lack of research and development in the cotton sector of Pakistan has resulted in low quality of cotton in comparison to rest of Asia. Due to the low profitability in cotton crops, farmers are shifting to other crops such as sugar cane. It is the lack of proper research and development that has led to such a state [15].

\section{Dependency on cotton}

As discussed earlier, Pakistan's textile industry is dependent on cotton and cotton production. Therefore, Pakistan's textile industry is diminished due to the decreasing cotton production. As discussed in the introduction part, Pakistan mostly imports man-made filaments and staples (fibres, yarns and fabrics). In other terms, it imports synthetic fibres, yarns and fabrics which are widely used inclothing and technical textile production. Therefore, dependency on cotton restricts diversification of Pakistan's textile export. Every year Pakistan spends million dollars on synthetic fibres imports (table 8).

\section{Low labour productivity}

It is concluded that, lack of qualified skilledand educated labour force is a big constraint for textile and clothing exports of Pakistan [1,5,16]. Although Pakistan is labour abundant country, its labour productivity is remarkably lower than rivals due to

\begin{tabular}{|l|c|c|c|c|c|}
\hline \multicolumn{6}{|c|}{ SYNTHETIC FIBRES EXPORT AND IMPORT FIGURES OF PAKISTAN (THOUSAND US DOLLAR) [9] } \\
\hline & $\mathbf{2 0 1 2}$ & $\mathbf{2 0 1 3}$ & $\mathbf{2 0 1 4}$ & $\mathbf{2 0 1 5}$ & $\mathbf{2 0 1 6}$ \\
\hline 54-Man-made filaments (fibre, yarn, fabric) export & 34,127 & 30,349 & 33,423 & 25,656 & 30,336 \\
\hline Annual \% change & - & -11.07 & 10.13 & -23.24 & 18.24 \\
\hline 54-Man-made filaments (fibre, yarn, fabric) import & 529,861 & 527,170 & 676,963 & 720,153 & 721,791 \\
\hline Annual \% change & - & -0.51 & 28.41 & 6.38 & 0.23 \\
\hline Foreign trade balance of man-made filaments & $-495,734$ & $-496,821$ & $-643,540$ & $-694,497$ & $-691,455$ \\
\hline 55-Man-made staple fibres (fibre, yarn, fabric) export & 449,180 & 418,173 & 417,658 & 302,343 & 220,487 \\
\hline Annual \% change & - & -6.90 & -0.12 & -27.61 & -27.07 \\
\hline 55-Man-made staple fibres (fibre, yarn, fabric) import & 539,396 & 532,440 & 766,145 & 782,754 & 687,043 \\
\hline Annual \% change & - & -1.29 & 43.89 & 2.17 & -12.23 \\
\hline Foreign trade balance of man-made staple fibres & $-90,216$ & $-114,267$ & $-348,487$ & $-480,411$ & $-466,556$ \\
\hline
\end{tabular}


unqualified and unskilled labour force. Labour productivity can be improved by proper training and education. Therefore, redundant raw material usage can be reduced and product quality can be increased.

\section{Insufficient infrastructure}

Adequate infrastructure consists of sufficient water resources, continuous electricity and gas supplies, efficient logistics and transportation, proper tax structure and abundant raw material. These are the basic requirements for industry development. However, Pakistan is deficient in terms of adequate infrastructure. Nowadays, Pakistan textile industry faces with increasing electricity and gas prices which directly affect the production costs [4]. industry. Therefore, Pakistan cannot be able to fulfil orders on time. However, customers demand their orders on time in order to launch their own products on time. Consequently, Pakistan loses customers [4].

\section{Textile machinery importation}

Pakistan has given foreign trade deficit in textile machinery trade over the past five years (table 9). Its textile and leather machinery import has approximately increased \%22 for the last five years. Therefore, Pakistan's textile and clothing sector is dependent on imported machineries.

The textile machinery used in Pakistan is imported mainly from countries like Japan, Switzerland, Germany, China and Belgium [14].

\begin{tabular}{|l|c|c|c|c|c|}
\hline & $\mathbf{2 0 1 2}$ & $\mathbf{2 0 1 3}$ & $\mathbf{2 0 1 4}$ & $\mathbf{2 0 1 5}$ & $\mathbf{2 0 1 6}$ \\
\hline 724-Textile and leather machinery export & 14,539 & 13,958 & 9,073 & 10,006 & 8,010 \\
\hline Annual \% change & - & -4.00 & -35.00 & 10.28 & -19.95 \\
\hline 724-Textile and leather machinery import & 439,315 & 498,101 & 584,915 & 515,227 & 537,486 \\
\hline Annual \% change & - & 13.38 & 17.43 & -11.91 & 4.32 \\
\hline Foreign trade balance of textile and leather machinery & $-424,776$ & $-484,143$ & $-575,842$ & $-505,221$ & $-529,476$ \\
\hline
\end{tabular}

Moreover, critics argue that the textile industry has obsolete equipment and machinery. The inability to timely modernize the equipment and machinery has led to the decline of Pakistan's textile competitiveness. Due to obsolete technology, the production costs are higher in Pakistan as compared to other countries like India, Bangladesh and China [15].

\section{Inadequate quality standards}

Pakistan textile industry is currently facing several challenges. There is a need for the industry to improve the quality of its products [14]. Some of the large scaled Pakistani textile companies produce according to the standards whereas most of the small and medium sized companies do not focus on quality standards. Most of the small and medium sized companies purchase second-hand textile machines from China, India and South Korea. However, their machinery buying criteria only consist of cheapness and workableness. Consequently, these old machines are very poor in terms of quality and textile products which are produced by these machines possess low quality [5]. This situation usually ends with international customer and market loss. If an industry wants to be successful in international markets, it has to provide best quality. Therefore it has to produce according to the quality standards which are accepted globally.

\section{Business management issues}

Pakistan misses many opportunities due to the lack of professionalism, which is the basic requirement of today's business life. In addition, supply chain management is the key factor of successful business. However, supply chain management is rarely implemented in Pakistan's textile industry. This situation is resulted in disorganized, disconnected and distorted
Opportunities for Pakistan's Textile and Clothing Industry

\section{International marketing and collaboration}

Marketing can be defined asan art of product and service presentation. Marketing techniques are used in order to build good relationships with customers, present products and services outstandingly and take advantage of opportunities. If Pakistan invests in marketing techniques and marketing employees, it can easily increase its share within global textile and clothing trade.

Pakistani textile companies must reduce production costs, improve labour efficiency, apply quality standards, produce high value-added products, use marketing techniques successfully and penetrate into foreign markets. In this context; collaboration with other successful foreign companies can be useful, because a company can learn lots of things from its partners (suppliers, rivals, collaborators etc.).

\section{Recent regional cooperation}

The Shanghai Cooperation Organisation is a permanent intergovernmental international organisation, the creation of which was announced on 15 June 2001 in Shanghai (China) by the Republic of Kazakhstan, the People's Republic of China, the Kyrgyz Republic, the Russian Federation, the Republic of Tajikistan, and the Republic of Uzbekistan. It was preceded by the Shanghai Five mechanism [19]. For the first time since its 2001 inception, the Shanghai Cooperation Organization has a pair of new members. By simultaneously adding Pakistan and India to the organization in June 2017, now it represents nearly half of the global population, as well as significant economic and geographic heft [20]. Therefore, 
this regional cooperation is a huge opportunity for Pakistan's textile and clothing industry.

\section{Recent developments in global economy}

Global economic activity is picking up with a longawaited cyclical recovery in investment, manufacturing, and trade. World growth is expected to rise from 3.1 percent in 2016 to 3.5 percent in 2017 and 3.6 percent in 2018 [21]. According to the latest projections by the World Bank, in emerging and developing economies, growth is projected to accelerate to 4.2 percent in 2017 from 3.4 percent in 2016 [22]. Pakistan's textile and clothing industry can find new markets and increase its exportation due to these recent developments in global economy.

\section{Domestic market}

In addition to increasing global demand, Pakistan also enjoys a huge domestic demand owing to its huge population size [14]. Domestic demand is raised due to the recent migration of the population from the agrarian society to the urban areas, increased income levels and population growth [16]. its competitiveness to other countries, especially in South East Asian countries [14]. Bangladesh, India and China are rivals of Pakistan in its major export markets (European Union and USA) in terms of textile industry. Also the recessions in the West has resulted in a slowdown in demand for textile products. Due to all the other problems faced by the textile industry, its production capacity and quality continues to decrease. Therefore, Pakistan is lagging behind its competitors and it is a huge threat for Pakistan's textile industry [5].

\section{Increased costs}

Pakistan textile industry possesses higher labour costs, longer labour hours, higher electricity and transportation costs (table 10). In addition to these building costs in Pakistan are extremely high according to its rivals. Therefore, total production costs are increased due to high input costs.

In addition to these, shortage of electricity, high interest rates, double digit inflation and descending value of Pakistani rupee also increase the production costs because the production of textile industry is

Table 10

\begin{tabular}{|l|c|c|c|c|c|}
\hline \multicolumn{1}{|c|}{ Cost category } & $\mathbf{1}$ (lowest) & $\mathbf{2}$ & $\mathbf{3}$ & $\mathbf{4}$ & $\mathbf{5}$ (highest) \\
\hline Labour cost & Bangladesh & Cambodia & Pakistan & India & China \\
\hline Labour hours & Bangladesh & China & Pakistan & India & Cambodia \\
\hline Electricity cost & Bangladesh & China & Pakistan & India & Cambodia \\
\hline Ocean transport cost & China & Bangladesh/Cambodia & Pakistan & India & - \\
\hline Land transport cost & Bangladesh & Pakistan & India & China & Cambodia \\
\hline Building cost & China & Bangladesh & Cambodia & India & Pakistan \\
\hline
\end{tabular}

\section{Clothing production}

Pakistani textile and clothing companies should produce and sell high value-added products in order to compete with their rivals and increase their market share. In this context, selling clothes instead of raw cotton would be better in terms of earning profit. Therefore, Pakistani textile and clothing companies should be focused on clothing production.

\section{Production of technical textiles}

Technical textiles gain more importance from day to day. Therefore, Pakistan must give great importance to this segment. However, neither government nor the textile companies pay attention to this segment. Pakistan spends excessively every year during technical textile (aerospace, military, marine and medical products) importation. Although textile is the backbone of Pakistan's economy, the sector only focuses on conventional products. Therefore, Pakistani textile and clothing companies should be focused on technical textile production.

\section{Threats for Pakistan's Textile and Clothing Industry \\ International competition}

Textile industry is one of the oldest industries in Pakistan and in spite of its inherent strengths; it loses decreased due to these challenges whereas its fixed costs are remained same. Besides, cotton and other raw material prices fluctuate rapidly in Pakistan [15, 24]. Therefore, Pakistan textile and clothing industry should find a way for cost reduction in order to gain competitiveness.

\section{Energy crises}

Energy prices vary from country to country. In this context, Pakistan possesses higher electricity prices than its rivals (table 11). In this context, production costs are increased due to the increasing energy prices.

Currently in Pakistan, there is an acute shortage of energy and it is indeed facing one of the worst energy scenarios since its birth back in 1947. The shortfall of electricity, natural gas and petroleum products

\begin{tabular}{|c|c|}
\hline Country & $\begin{array}{c}\text { Average price } \\
\text { (US\$/KWh) }\end{array}$ \\
\hline Bangladesh & 0.0418 \\
\hline China & 0.0650 \\
\hline India & 0.0433 \\
\hline Pakistan & 0.0491 \\
\hline
\end{tabular}


has greatly affected the daily life of almost every Pakistani. Presently, industrial and agricultural growth are on the decline due to the shortage of energy which gave birth to many vices like inflation, unemployment, unrest, everyday strikes, street crimes, intolerance in the society and increase of the poverty level in the country [25].

\section{Unstable political and economic situation}

Unstable political situation and corrupt system in the country are one of the major reasons of industrial decline. Industrial activities cannot be performed in a disturbance and fear atmosphere. Besides, Pakistan is a country where policies are rapidly changed even in days and weeks. Moreover, the recent terrorist attacks within the country results in high freight costs. Therefore, textile industry cannot develop properly without long-termed and consistent policies [5].

\section{Fast fashion}

Nowadays, product life cycles within the clothing sector are shortened due to the rapid alterations and fashion concept. Companies frequently present new collections to their customers in order to comply with fast fashion. In this context, fast fashion poses a threat to Pakistan's textile and clothing industry because Pakistan is lack of new machines, fast and efficient production and qualified labours. Therefore, customers prefer Pakistan's rivals even at higher costs due to the deadline issues.

\section{CONCLUSIONS, GENERAL EVALUATION AND SUGGESTIONS}

Pakistan's textile and clothing industry has recently gone through serious and strategic processes. Global developments also seriously affect these strategic processes. However, textile and clothing industry is mostly affected by internal issues such as high electricity prices, frequent power cuts, devaluation of Pakistani rupee, high production costs, political uncertainties, low labour productivity, inadequate quality standards, insufficient infrastructure and absence of research and development activities. These issues negatively affect competitiveness and exportation of textile and clothing industry.
In spite of these issues, Pakistan's textile and clothing industry has an important place in Pakistan's economy. Also it is the seventh biggest textile exporter of the world. Therefore, significant precautions should be taken in order to improve and enhance this industry. As a consequence, some suggestions are made for Pakistan's textile and clothing industry.

1. Short, medium and long term policies and incentive implementations of government must be reviewed and activated.

2. Pakistan's textile and clothing industry is dependent on cotton and cotton production. However, the industry must be focused on clothing and technical textile production. In other words, it should produce and sell high value added products. Thus, exportation amounts and values can be increased.

3. Although Pakistan is labour abundant country, it lacks for qualified labour force. Its labour productivity is remarkably lower than its rivals. Labour skills and productivity should be improved by proper training and education.

4. Pakistan possesses higher energy prices than its rivals. Production costs are increased due to the increasing electricity and gas prices. Besides, power cut (electricity and natural gas cuts) is the main problem of Pakistan's textile and clothing industry. Therefore; continuous, adequate and cheaper power should be supplied.

5. All Pakistani textile and clothing companies should pay attention to international quality standards. The products must be manufactured according to these standards.

6. All Pakistani textile and clothing companies should invest in technology. High technology is helpful in terms of product quality and customer satisfaction.

7. Pakistan is dependent on textile machinery importation. Therefore, companies should invest to this segment.

8. Pakistan's textile and clothing industry should pay attention to accurate business management in order to prevent from disorganized, disconnected and distorted industry.

To sum up, textile and clothing industry's share and efficiency within Pakistan economy should be increased progressively and permanently.

\section{BIBLIOGRAPHY}

[1] Khaliji B.A., Jaffari S.I.A., Shahzad A., Mehtab M. Role of textile sector in domestic resources development, In: Business Management Dynamics, 2013, 2(10), pp. 14-27.

[2] World Trade Organization, Statistics Database, Time Series on International Trade, http://stat.wto.org/Statistical Program/WSDBStatProgramHome.aspx?Language=E (Date of Access: November 2017)

[3] Pakistan Textile Journal, Annual Fact File 2015,http://www.ptj.com.pk/Web-2015/12-2015/December-2015-PDF/ Annual-Fact-File-2015.pdf (Date of Access: July 2017).

[4] Akhlaq M.A.,SWOT analysis of the textile industry of Pakistan, In: Pakistan Textile Journal, 2009,August 2009, pp. 37-39.

[5] Siddique R., Shaheen I., Akbar W., Malik M.A., Syndicate Report-VI, Pakistan's Federal Board of Revenue, 37p., https://tr.scribd.com/document/114042237/6 (Date of Access: July 2017). 
[6] Ahmad N., Kalim R. Implications of export competitiveness and performance of textile and clothing sector of Pakistan: pre and post quota analysis, In: Pakistan Journal of Commerce and Social Sciences, 2014, 8(3), pp. 696-714.

[7] Luchnikava H., Pakistan Country Intelligence Report, IHS Global Insight, 2012, 25 p.

[8] World Trade Organization, World Trade Statistical Review 2017, 2017, 181 p.

[9] International Trade Center, Trademap - Trade Statistics for International Business Development, http://www.trademap.org/lndex.aspx (Date of Access: July 2017).

[10] Harmonized System (HS) Classification Code Explanations, http://www.foreign-trade.com/reference/hscode.htm (Date of Access: July 2017).

[11] Butnariu A., Condurache G. SWOT analysis of the efficinecy in the production of technological steam for the textile materials finishing, In: Industria Textila, 2013, 64(6), pp. 342-345.

[12] Cotton Incorporated, Monthly Economic Letter, August 2017, http://www.cottoninc.com/corporate/MarketData/MonthlyEconomicLetter/pdfs/English-pdf-charts-and-tables/World-Cotton-Production-Bales.pdf (Date of Access: August 2017).

[13] Minimum wages of textile workers in textile industry in Pakistan, http://www.paycheck.pk/main/salary/minimumwages/minimum-wages-2011-1/textile-industry(Date of Access: July 2017).

[14] Iqbal M.S., Shaikh F.M., Mahmood B., Shafiq K. Development of textile industrial clusters in Pakistan, In: Asian Social Science, 2010, 6(11), pp. 123-140.

[15] Khan A.A., Khan M. Pakistan textile industry facing new challenges, In: Research Journal of International Studies, 2010, 14, pp. 21-29.

[16] Jaleel R., Ishfaq A., Saleemi A., Samin T. SWOT analysis of textile industry in Pakistan, In: Asian Journal of Research in Business Economics and Management, 2014, 4(9), pp. 76-87.

[17] United Nations Comtrade, International Trade Statistics Database, https://comtrade.un.org/data/ (Date of Access: July 2017).

[18] SITC Revision Code 72 Explanation, https://unstats.un.org/unsd/cr/registry/ regcs.asp?Cl=14\&Lg=1\&Co=72 (Date of Access: July 2017).

[19] Shanghai Cooperation Organisation, About The Shanghai Cooperation Organisation, http://eng.sectsco.org/ about_sco/ (Date of Access: July 2017).

[20] Michel C., 2017, It's Official: India and Pakistan Join Shanghai Cooperation Organization, https://thediplomat.com/ 2017/06/its-official-india-and-pakistan-join-shanghai-cooperation-organization/ (Date of Access: July 2017).

[21] International Monetary Fund, World Economic Outlook, April 2017: Gaining Momentum? http://www.imf.org/en/ Publications/WEO/Issues/2017/04/04/world-economic-outlook-april-2017 (Date of Access: July 2017).

[22] The World Bank, Global Economy in 2017: Hope and Uncertainty, http://www.worldbank.org/en/news/ opinion/2017/02/15/global-economy-in-2017-hope-and-uncertainty (Date of Access: July 2017).

[23] United States Agency for International Development (USAID), Cost competitiveness of Pakistan's textiles and apparel industry, 2009, http://pdf.usaid.gov/pdf_docs/PA00JBZ6.pdf(Date of Access: July 2017).

[24] Afzal M.Y. Impact of electricity crisis and interest rate on textile industry of Pakistan, In: Academy of Contemporary Research Journal, 2012, 1(1), pp. 32-35.

[25] Farooq M., Shakoor A. Severe energy crises and solar thermal energy as a viable option for Pakistan, In: Journal of Renewable and Sustainable Energy, 2013, 5, doi:10.1063/1.4772637.

\section{Authors:}

\section{SEHER KANAT ${ }^{1}$, SADAF AFTAB ABBASI ${ }^{2}$, MAZHAR HUSSAIN PEERZADA ${ }^{2}$, TURAN ATILGAN ${ }^{1}$}

${ }^{1}$ Department of Textile Engineering, Ege University, İzmir, Turkey

${ }^{2}$ Department of Textile Engineering, Mehran University of Engineering \& Technology, Jamshoro, Pakistan

\section{Corresponding author:}

\section{SEHER KANAT}

e-mail: seher.kanat @ege.edu.tr 